Journal of Social Sciences (COES\&RJ-JSS)

ISSN (E): 2305-9249 ISSN (P): 2305-9494

Publisher: Centre of Excellence for Scientific \& Research Journalism, COES\&RJ LLC

Online Publication Date: $1^{\text {st }}$ April 2017

Online Issue: Volume 6, Number 2, April 2017

http://centreofexcellence.net/J/JSS/JSS\%20Mainpage.htm

\title{
Peer counseling in perspective of Pesantren
} Yuliati Hotifah

Senior Lecturer, Guidance and Counseling Department Faculty of Education, Malang State University,

Malang, East Java, Indonesia

\begin{abstract}
:
This study reports development of peer-counseling on the basis of Islamic boarding school (the-so called pesantren) system. This study used Research \& Development design, assigning santris in three pesantrens in East Java: Arekan in Banyuwangi, the Borders in Pasuruan, and Mataraman in Blitar. The study was conducted in two phases: development of training modules and training guides. Data were collected using questionnaires, interviews, observation and documentation. The study revealed: (1) Problems faced by santri are: individual, other, environment, individual-environment, individual-other, environment-other, environment-individual-other. (2) Santri in the age range of adolescents are in a phase of self-searching that is full of hardships and problems. (3) Problems in adherence to activities in pesantren include issues private life, social, learning and ability in adaptability of life pattern of pesantren.

Keywords:

Peer counseling, boarding school, pesantren, character building.

Citation:

Hotifah, Yuliati (2017); Peer counseling in perspective of Pesantren; Journal of Social Sciences (COES\&RJ-JSS), Vol.6, No.2, pp: 291-299.
\end{abstract}




\section{Introduction}

Pesantren or Islamic Boarding School is a double-function education system offering integrated informal and formal education system in Indonesia. Pesantren has its functions to equip self-development of santri (students of pesantren) through various facilities and infrastructures in the pesantren. Historically, pesantren was the predecessor of boarding schools that has long been held in the Western world. Benefits of pesantren compared with regular school system is that santris are staying in an environment of educational atmosphere for 24 hours, and educators or caregivers can supervise, guide and give a role model to them as well for 24 hours. Due to the nature of methodology and atmosphere of a familiar environment, pesantren has the ability to create a brotherhood friendly lifestyle, with a cooperative spirit, independence, and free-and-responsible manners. Pesantren system is possible to gauge educated individuals that are resilient and have strong characters. This personal building is often more important than mere knowledge to gain success in life.

Counseling management process as reflected in the pesantren is expected to bridge a real social practice into a process of group dynamic. Counseling that lies on the needs of social practice is designed by counsellor on the basis of psychosocial management. It requires social organizations that functions to gear group dynamics within the smallest scope in pesantren. Counseling is an activity that directs operation of a partial form of mentoring.

\section{Review of literature}

Development of counseling at pesantren in this concept combines indigenous counseling approach that compiles component of local culture with discourse theory of social ecology and field theory that embodies subculture and culture as macro-system and supra-systems process to form behavioural and psychological development of humans (Brofenbrenner, 2005; Rudkin, 2003). Device of culture is an object that cultural values are transmitted (Rudkin, 2003). Pesantren has a number of cultural devices because it takes a position as a subculture community. Counterfeit culture in pesantren has various style, depending on model and modification of the pesantren. This diversity is determined by the objective needs to match available input. Some pesantren teach students merely Islamic religion, some serve formal approach using modern management, and the others try to perform functions of collaborative community development (Wahid, 2001; A'la, Anisah, Aziz, \& Muhaimin, 2007).

Pesantren cultures evolve and converge in a tradition that moves circling relational system between individuals in the pesantren. The culture is inherited through various modelling techniques, symbolism, appreciation, organization, and self-transformation for sequencing process of psychological development of santri. The series of cultural significance forms psychosocial cohesion and are articulated in various individual strengths, social, environmental, trust, spirituality and religious dynamics of the students. The cultural values are transmitted through teaching, rituals, religious practice, habituation, modelling, discussion, reflection, race, mujahadah, consistency, devotion (courtiers), that are rooted into the history of pesantren (Hotifah, 2013). The cultural characteristics of pesantren had become the locus and mode of social environment conducive to transformation and development of counseling. Implementation of counseling as a way to guide santris to overcome problems yet have no form corresponding with mission of teaching at the pesantren itself. If there are santris who have problem, the solution is directed to uztads, 
even if it is severe, the problems are directed to the Kyai. The problems are overcome through instructive advices and religious doctrines.

Majority of santris when faced with problems does not directly express to the kyai, but they tell to fellow santri. The fellow santris are considered the most appropriate to tell and understand better on the condition. In an effort to help solve the problem, fellow santri does not advise too much but share the opportunity to devote all felt (Bolton, 2000).

The assistance from fellow santris is effective to alleviate the problems. Different when consulting to the uztads or Kyai, the santris feel there is too much distance between himself and the uztads; they could not fully communicate the problems and feelings freely. The assistance from the Kyai inclines the form of advice or prayers that are considered to give no help for them, even sometimes they feel overwhelmed mentally. In essence, if the problems were never solved completely, santris will break out the rules outside the system. Deviant behaviour is likely to occur because the santris do not know the way to solve. Santris were away from pesantren and brook the rules.

Urgency of development of pesantren-based peer counseling model in addressing the problems is required here. It refers to some cases: (1) approximately $90 \%$ of the santri problems are handled traditionally using instructive advice, (2) social control to enforce rules is punishment, or Ta 'zir, (3) problem that can not be handled by uztads is submitted to Kyai, (4) the santris have a culture of "reluctant" to the uztads and Kyai so they can not freely express the problems being faced, and (5) the santri feels more freely if he shares issues to his friend. It is evidence that pesantren-based peer counseling model is badly needed.

\section{Methods}

The study was Research and Development (R\&D). The development process was conducted in two phases: development of training modules and training guides (Borg, \& Gall, 2003). Subjects consisted of expert on counseling, experts on learning model design and students as trainee. The subjects were selected from three pesantrens that represented characteristics of East Java: An-Nur Bululawang (Arekan area), Al-Yasini Areng-Areng Pasuruan (boarder area) and Hidayatul Mubtadiin Blitar (Mentaraman). Sample was selected using participant group of proportional method and purposive random sampling. Data were collected using questionnaires, interviews, observation and documentation and were analyzed on qualitative and quantitative forms.

\section{Results}

\section{Types of Problems Faced by the Santri}

Problems faced by santri consisted: individual, other, environment, individualenvironment, individual-other, environment-other, environment-individual-other. Individual problems included: courtship, self-identity, catching attention, selfmanagement, and jealous to friends. Environment problems comprised medical facilities and too strict rules. Problems on individual and environment covered adherence to the rules, smoking, going home before holiday, and prejudice to others. Problems on individual and others were in terms of forced to learn and stay at pesantren by parents, sickness, hard to learn lessons, and understanding of teachers. Others-environment and individual problems included: inadequate cleanliness of the rooms, limited times for refreshing, blorot (drop out), and boyong (moving from the previous room). Boyong 
occurred every year as around $6.4 \%$ santris enrolled to stay at pesantren. As new sanri entered, older santri staying in one room may have to move to other room resulting problems on environment for the santri.

Problems faced by adolescents occurred to santri who are searching self-identity. The santris experienced psychological turmoil that affected deviant behaviour. Santris as teens have a developmental task that have to follow system and rules applied in pesantren. Developmental tasks that are not actualized properly will result developmental disorder, such as psychological imbalance or even psychological disorders.

\section{Internal Problems of the Santri}

Santri in the age range of adolescents are in a phase of self-searching and face full of hardships and problems. This development phase lasts long enough approximately 8 years, ranging in age from 11-18 years for women and 2-20 years for men. The phase is identified by rapid physical growth, high self-awareness, and is always keen to try something new. Teens are not the last time to form personality but it is the main stage in the formation of one's personality. Teens spend more time with his peers.

Adolescents receive more information from the mass media. Therefore, they are individuals who are open to new things (Corey, 2005). The information makes teens perform information processing in more depth. This phase is a search of individual identity because teen is in between two junctions of children's world and the world of adults. The existence of teens in between two intersections makes them full of difficulties and problems. Certainly, a person in a state of transition or in on going transition from one state to another, often experiences turbulence and shocks that can sometimes be fatal. All difficulties and problems arising in this phase can be minimized or eliminated, if parents, teachers and the public understand adolescent mental development to increase their confidence.

\section{External Problems of the Santri}

Problems of dynamics of santris as teenagers in adherence to activities in pesantren include issues on private life, social, learning and ability in adaptability of life pattern in pesantren. Each problem has its own characteristics and patterns that require different approach to solve. This study copes with local wisdom, as the basis of exposure for the santri to share.

Providing a place for adolescent santri gives attention to social needs of their emotional in terms of trust. Initially, the results are: (1) approximately $90 \%$ of the santri having problem are handled traditionally using instructive advice, (2) social control used to enforce is punishment or Ta 'zir, (3) problem that can not be handled by the uztads is submitted to Kyai, (4) the santris have a culture of "reluctant" to the uztads and Kyai so that they can not freely express the matter at hand, and (5) the santris are more freely if they share issue to his friend.

In public, the santris are imaged as a good individual having good morale, and adhere to conduct rules and expectations of society. If a santri brook the rules at a little bit, the initial image will change. The rules imposed on pesantren are not binding rules that does not uphold human rights, but it instils discipline. Rules by rules must be understood and be 
implemented thoroughly. In this case the santris require to get guidance from older people and support from fellow santris.

\section{Prototype of Conceptual Pesantren-Based Peer-Counseling Model}

Figure 1 describes a prototype of conecptual peer-councelling model used to develop the foundation of development of peer-counseling that are based on local wisdom of pesantren.

Conditions regarding the lives of santris and their problems need immediate solution. If the problems are never solved completely, the santris will seek their own way to solve. Deviant behaviour will occur because the santris do not know what to do to solve the problems. Santris running away from pesantren, breaking rules and the like indicate that accumulation of problems is not resolved properly.

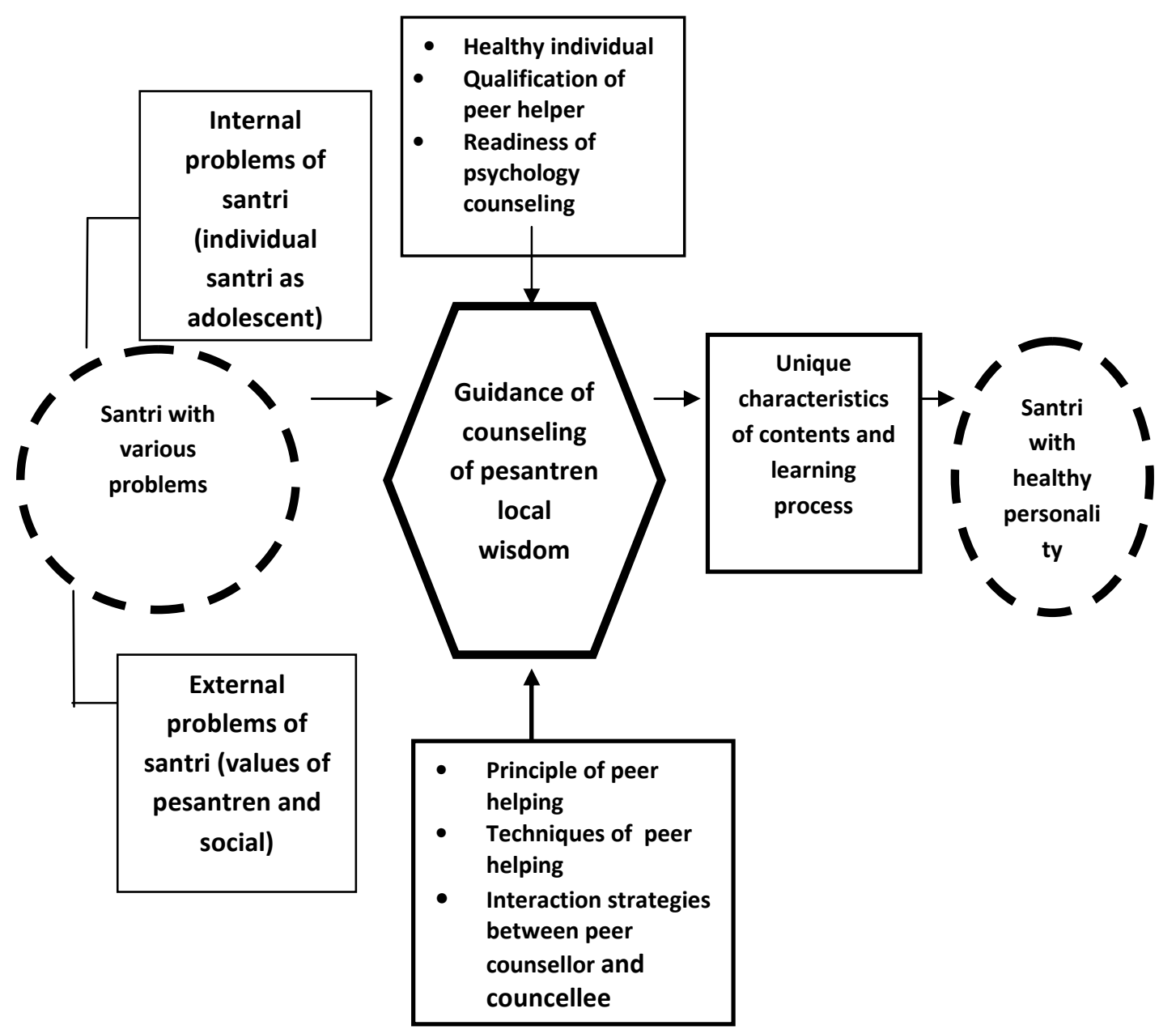

Figure 1. Prototype of Conceptual Pesantren-Based Peer-Counseling 


\section{Discussion}

The theoretical framework in this study used indigenous counseling theory perspective. Indigenous counseling presents an approach to a context (family, social, cultural, and ecological) contents (meaning, values, and beliefs) explicitly incorporated into the design of the study (Corey, 2005). Indigenous psychology is a scientific study of human behaviour or natural thoughts that are not transported from other regions and is designed for people. The indigenous counseling advocates to examine the knowledge, skills, and beliefs that people have about themselves and assess these aspects in a natural context. The role of religion in indigenous counseling is the most important aspect (Chirzin, 2007). Characteristic of Islamic counseling lies in the use of vibrating faith (power ruhaniyah) in overcoming psychological problems. The study of the human psyche are within the scope of science of morality and mysticism (Cowie, and Wallace, 2000).

Implementation of Sufism approach to assess pesantren is not enough, because the formation of values in pesantren used fiqh law as an important role (A'la, A., Anisah, H., Azis, A., \& Muhaimin, A. 2007; Grotberg, 1995). Pesantren will refer their everyday behaviour to provisions contained in the fiqh books and exemplary manners of Sufism. Like human, the body is fiqh, and the spirit is Sufism. The pesantrens are so closed to local tradition and it never escapes from tradition of local community into its social base. This way, pesantren is more visible hallmark of "Javanese Islam" or "Islamic Cultural" (Hotifah, 2011; Mahpur, 2008). Source of values of pesantren is the integration between Islamic values contained in the books of fiqh and Sufism to the local culture.

Its comprehensive function and holistic approach makes pesantren to hold 12 principles in running education. They are: (1) Theocentric; (2) Voluntary devotion; (3) wisdom; (4) simple; (5) collectivity; (6) organizing of joint activities; (7) freedom in guidance; (8) independence (9) pesantren as a place to seek knowledge and to serve; (10) the teachings of religion (11) studying in pesantren not to find a diploma (12) blessing of the Kyai for all actions undertaken by citizen in pesantren. Values attached to an individual santri are tasamuh, ta'awun, tawazun, and orientation to realize khoiro ummah.

Santris as students studying in pesantren and are classified into: residing santri (santri mukim) and part-timer santri (santri kalong). Mukim santris are students coming from other areas and settle in the boarding group. Kalong santris are students from the surrounding community of pesantren that do not settle in pesantren. To follow lessons at the pesantren, they go back and forth from their homes. There is also a "wanderer santri" to show students who moved to learn from one to other pesantren to deepen the knowledge of expertise of a cleric. After a pesantren adopts a system of madrasah (Islamic formal school) tradition of wanderer santri is no longer acceptable. In general, pesantren require elements of the Kyai who teach, educate and perform as a role model for the santris; the mosque as a place to provide education and prayer of worshipers, and dormitory where the santris stay. Institutionally, pesantren can also be seen from the organization, i.e. institutional status, organizational structure, leadership style, and leadership succession.

Basically, pesantren has two wings: wings that keep values of absolute truth and wings that preserve values of relative truth. The first wing is responsible for preservation of purity of truth or religion, while the second wing is responsible for the practice of absolute 
values inside and outside the pesantren. The teachings of the Kyai, uztads, and religious texts that are taught in pesantren is believed to have the absolute truth by the santris. The truth of teachings and validity of a doctrine being delivered is not questionable; the santris just try to understand and practice the teachings.

The most prominent difference between pesantren in the growing era and in the development era exists. Pesantren in the growing era is more focused on transition of mysticism. In the development era pesantren varied, showing distinctive characteristics on the curriculum being implemented. In the growth of pesantren in the 16th to 18th century, yellow books had already been learned by Muslims. It was the books of pantheistic mysticism, especially the only two fiqh: Al-Fiqh al Taqrib Fi and Al-Fiqh al Idhaah Fi and two Tafsir: Al-Jalalayn and Al-Baidhawi. Intellectual insight in the 16th to 8th century was considered broader than in the 9th century. The reason is that the books of Sufism were comprehensively studied during the era, including philosophical Sufism and mysticism orthodox. In the development era, books to be studied were just orthodox Sufism, such as the Ihya Ulumuddin (Nuqul, 2008).

In the era of development, salafiyah pesantren had been operated and it taught yellow books of fiqh, tafsir and Sufism. There were also a tool pesantren that focused on the study of naahwu, shoraf; and Alquran pesantren that specialized to teach memorizing scripture and qiroat (reading al-Quran). Education at pesantren in general was a combination of Salafi and Kholafiyah. Kholafiyah pesantren operated Kindergaten Formal Education (Raudhatul Adfal), Primary School (Madrasah Ibtidaiyah), Secondary School (Madrasah Tsanawiyah) and Senior School (Madrasah Aliyah). Teaching and learning in this pesantren were conducted in the afternoon until evening. Learning methods used in the pesantren in East Java were traditional contemporary method that relied upon the habits practiced for long time and modified with the needs of the era. The methods were: sorogan, Bandongan (wetonan), Deliberation (Bahtsul Masail), memorizing (Muhafadzah), Demonstration, study tour (Rihlah ilmiah), muhadatsah, and Mudzakarah

In addition, healthy personal is personal which reflects the best human beings (Khaira Ummah), as in the Qur'an Surah Ali Imron: 110. Person who holds Khaira Ummah indicates individual that always calls to goodness, prevents from sins, and keeps faith in God. Misplaced manners means being personal distorted and the opposite of God. Healthy individual is a personal that as far as possible carry out duties as servants of God (worship) and the caliph of God (build civilization and prosperity). Al-Ghazali said life is a love and worship (al-hayah mahabbah). Man as a caliph has a task to prosper society with values of goodness, virtue, and instructions. Besides, humans can also uphold justice, equality, compassion, mercy, plead to the weak, help the oppressed, fight the people in accordance with their ability to manifest the life of a happy and prosperous (Santrock, 2004).

To serve that duty, Islamic law were derived. Scholars agreed that Islamic law is intended to realize the benefit of man (al-mashlahah), physical and mental, and in the world to the next. "Al-mashlahah includes all kinds of goodness, interests and benefits under the five principles of universal (al-Kulliyat al- khams): maintenance of religion (hifzh al-din), existence of reason and freedom of thought (hifzh al-'aql), salvation of souls and the whole body (hifzh al-nafs), possessions (hifzh al-mal), and heredity (hifzh al-nasl). All components are the actual implementation of the five principles of the universal, as stated 
in Islamic requisites on the health. Spiritual health refers to the principle of hifzh al-din; the health of mind refers to hifzh al-'aql; the health of body refers to hifzh al-nafs, the health of economy refers to hifzh al-Mal and social health refers to hifzh al-nasl and hifzh al -'irdh, to maintain the honor (Tindall, and Gray, 1985). To sum up, healthy personal is an individual that makes balance elements of ritual piety and social piety. Ritual piety is a reflection of faith attitude and embodiment of God's servants. Social piety reflects commanding good and prohibiting unjust and embodiment of God's caliph who served prosperity and built prosperous civilization, as the essence of Khaira Ummah personality.

\section{Conclusion}

The unique characteristics in pesantren and problems are very complex that it can only be handled by the managers of pesantren exclusively, but it must involve santris who faced the problems. Involving santris to solve problems experienced by the santris is by developing a peer helper. Peer helper at the pesantren was proved to have advantages in terms of solving problems of fellow students. Selection of peers who serve as helpers were based on credibility and capability as well as learning achievements obtained during the study at the pesantren.

\section{References}

A'la, A., Anisah, H., Azis, A., \& Muhaimin, A. 2007. Praksis Pembelajaran

Pesantren. Yogyakarta: Yayasan Selasih dan Forum Pesantren

Bronfenbrenner, U. 2005. Making Human Beings Human Bioecological Perspectives on Human Development. California: Sage Publication.

Bolton, R. 2000. People Skills: How to Assert Yourself, Listen to Others, and Resolve Conflicts. Sydney: Simon \& Schuster.

Borg, W.R. \& Gall, M.D. 2003. Educational Research: An Introduction. Third edition. New York: Longman

Rudkin, J. 2003. Community Psychology Guiding Principles and Orienting Concepts. New Jersey: Prentice Hall.

Corey, G. 2005. Theory and Practice of Counseling and Psychotherapy. (7'th eds.). Canada: Brooks/Cole.

Chirzin, M.H. 2007. Pesantren Selalu Tumbuh dan Berkembang. In N. M.D, A. A'la, H. Anisah, A. Azis, \& A. Muhaimin, Praksis Pembelajaran Pesantren (pp.vii-x).

Yogyakarta: Forum Pesantren dan Yayasan Selasih.Hotifah, Yuliati. 2013.

Cowie, H., dan Wallace, P. 2000. Peer Support in Action: From Bystanding to Standing By. London: Sage Publications

Grotberg, E. 1995. A Guide to Promoting Resilience in Children: Strengthening the Human Spirit. The Series Early Childhood Development: Practice and Reflections. Number 8. The Hague: Bernard van Leer Foundation.

Hotifah, Yuliati. 2010. Kesehatan Mental Santri dan Terapinya Menurut Islam. Jurnal Egalita; Jurnal kesetaraan dan Keadilan Gender. 5(1): 12-23.

Mahpur, M. 2008. Mengembangkan domain (kearifan) pesantren sebagai Medan Sosial Santri. Psikoislamika, JPI. 5(2): 125-146.

Nuqul, F.L. 2008. Pesantren Sebagai Bengkel Moral, Optimalisasi Sumber Daya Pesantren untuk Menanggulangi Kenakalan Remaja. Psikoislamika, JPI. 5(2): 163 182.

Pengembangan Model Penolong Sebaya Berbasis Kearifan Lokal Pesantren di Jawa Timur. Laporan Penelitian DP2M Universitas Negeri Malang. Tidak diterbitkan. 


\section{Peer counseling in perspective of Pesantren}

Santrock, J.W. 2004. Life-Span Development. Ninth Edition. Boston: McGraw-Hill Companies.

Tindall, J.D. and Gray, H.D. 1985. Peer Counseling: In-Depth Look At Training Peer Helpers. Muncie: Accelerated Development Inc. 